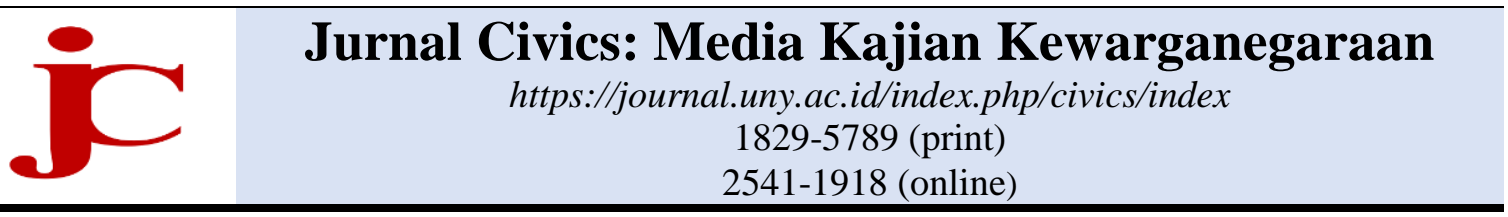

\title{
Usaha perantau Minangkabau di Kota Yogyakarta dalam membina hubungan dengan kerabat asal
}

\author{
Puji Wulandari a, ${ }^{*}$, Setiati Widihastuti ${ }^{\text {b, } 2}$, Iffah Nurhayati ${ }^{\text {c, } 3}$ \\ ${ }^{\text {a, b, c }}$ Fakultas Ilmu Sosial, Universitas Negeri Yogyakarta, Sleman, Indonesia \\ ${ }^{1}$ puji_wulandari@uny.ac.id*; ${ }^{2}$ setiati_widi@uny.ac.id; ${ }^{3}$ iffah_nurhayati@uny.ac.id \\ *korespondensi penulis
}

\begin{tabular}{lll}
\hline Informasi artikel & ABSTRAK \\
\hline Sejarah artikel: & Artikel ini bertujuan untuk menggambarkan latar belakang \\
Diterima & $: 05-10-2017$ & masyarakat Minangkabau yang terhubung dengan kerabat asal \\
Revisi & $: 02-05-2018$ & mereka. Bagi lelaki Minangkabau, bermigrasi berarti suatu \\
Dipublikasikan & $: 31-05-2018$ & keharusan, perjalanan awal untuk menjadi orang dewasa, \\
\hline Kata kunci: & mempersiapkan kehidupan yang lebih baik. Beberapa alasan \\
Minangkabau & untuk bermigrasi adalah (a) untuk kehidupan yang lebih baik; (b) \\
Kerabat asal & untuk belajar; (C) perlawanan sistem matrilineal. Faktanya \\
Perantauan & bahwa walaupun mereka merantau, mereka masih terhubung \\
& dengan kerabat aslinya. dalam beberapa bentuk, seperti bantuan \\
& keuangan untuk sepupu mereka, menjaga warisan leluhur, dan \\
& penggalangan dana untuk mengembangkan tanah leluhurnya. \\
& Selain itu, jejaring sosial baru didirikan untuk memahami \\
& tantangan baru dan untuk mengatasi kejutan budaya baru di tanah \\
& rantau.
\end{tabular}

Keywords:

Minangkabau

Relatives of origin

Migrating-out

\section{ABSTRACT}

The Effort of Minangkabau migrating-out in Yogyakarta in building relationships with relatives of origin. This essay was aimed at describing the background of Minangkabau society sustains their connection with homeland. For Minangkabau man, it is an obligatory task to migrate, the initiation to become fully adult, preparing for better life. The reasons for migration are (a) for a better life; (b) to learn; (c) to resist against matrilineal system. The fact is that they are still attached to their origin with some forms such as financial support for their cousin/nephew, to preserve sacred heritage, and to conduct fund-raising for their homeland. Furthermore, social networks were established to overcome the new challenges as well as cultural lag in a broad.

\section{Copyright $\odot 2018$ Puji Wulandari, dkk}

\section{Pendahuluan}

Secara tradisional, masyarakat Minangkabau menerapkan sistem matrilineal, yaitu menarik garis keturunan dari pihak perempuan, sehingga anak masuk ke dalam kekerabatan ibu dan mewarisi dari harta ibunya. Hubungan antara anak dengan bapak tidaklah dekat seperti dekatnya hubungan anak dengan ibunya karena di siang hari seorang bapak pergi mencari nafkah dan

hanya pulang di malam hari. Prinsip matrilineal masyarakat Minangkabau ini didukung oleh bentuk perkawinan semendo, yang mempunyai ciri mendatangkan laki-laki dari luar kerabat untuk tinggal di rumah kerabat istri (matrilokal), tetapi suami tidak ikut masuk ke dalam kerabat istrinya, melainkan tetap bertahan pada kerabat asalnya. Dalam sistem ini anak-anak masuk ke 
dalam suku ibunya dan bukan suku ayahnya. Suami tetaplah menjadi "orang asing" di lingkungan kerabat istrinya. Disebut sebagai urang sumando yang berarti orang yang didatangkan. Sebagai orang semenda, suami tidak memiliki kekuasaan di dalam rumah tersebut. Hubungan antara anak dengan ayahnya tidaklah dekat seperti dekatnya hubungan anak dengan ibunya. Para suami mencari nafkah guna memenuhi kebutuhan kehidupan kerabat pihak ibunya dan anakanaknya, sehingga pepatah Minang menyebutkan "anak dipangku, kemenakan dibimbing". Walaupun masyarakat Minangkabau berdasarkan garis keturunan ibu, namun yang berkuasa dalam kesatuankesatuan tersebut selalu orang laki-laki dari garis keturunan ibu, yang lazim disebut dengan istilah mamak. Seorang laki-laki yang sudah berumah tangga tetap berada dalam kerabat ibunya, beroposisi sebagai mamak. Falsafah minang tentang keharusan merantau jika belum berguna di kampung halamannya menjadi motivasi bagi orang minang mengadu untung di negeri orang. Bila disebut, tidak sejengkal tanah pun di Nusantara yang tak dijajaki orang minang. Bahkan ada guyonan, "kalaulah di bulan ada kehidupan, di sana orang minang pun akan suka merantau (Wibisono, 2012).

Seorang laki-laki Minangkabau beroposisi urgen sebagai mamak bagi kemenakannya dan saudara garis ibu "serumah gadang". Mamak memelihara, membina, memimpin kehidupan dan kebahagiaan kemenakan-kemenakannya, dan seluruh anggota keluarganya. Mamak berkewajiban membimbing anak kemenakan di dalam segala lapangan kehidupan. Tugas memelihara anak kemenakan ini bergantung pada berjalannya tugas yang lain. Sehingga dalam diri laki-laki Minangkabau melekat empat macam tugas, yakni: a) sebagai pemimpin bagi anaknya, b) pemimpin dari kemenakannya; c) pemimpin dari korong kampungnya, juga pemimpin di dalam masyarakat nagarinya atau Kerapatan Adat Nagari (Navis, 1984, hal. 36).
Keunikan lain dari masyarakat Minangkabau adalah tradisi merantau yang sudah tumbuh lama. Merantau merupakan ciri khas masyarakat Minangkabau, selain sistem kekerabatan matrilinealnya. Disebut sebagai ciri khas, karena merantau merupakan bagian kehidupan orang-orang Minangkabau yang terbangun dari budaya dinamis, egaliter, mandiri, dan berjiwa merdeka. Merantau adalah meninggalkan rumah dan kampung halaman untuk mencari pengetahuan, pengalaman, dan berinteraksi dengan orang lain dari beragam tempat, dengan beragam kultur, dan wawasan. Orang Minang telah memiliki tradisi bermigrasi meninggalkan tanah air mereka dan menetap di tempat lain yang dianggap memberikan kehidupan yang layak (Akmal \& Nurwianti, 2012). Terdapat tradisi yang mengharuskan pemuda Minangkabau merantau, sebelum mengabdikan dirinya di kampung halaman. Ini selaras dengan sebuah pantun Minang: "Karatau madang di hulu - Babuah babungo balun - Marantau bujang dahulu - Di kampuang baguno balun". Pantun di atas memotivasi pemuda Minangkabau untuk berani merantau, keluar dari kampung halaman guna menambah ilmu dan bekal kehidupan, karena tanpa itu mereka tidak akan bermanfaat bagi keluarga dan masyarakatnya. Merantau bagi laki-laki Minang adalah gerbang inisiasi yang harus dilalui untuk menjadi orang yang tangguh, dan harus dilakukan sewaktu berumur muda. Merantau merupakan proses pendewasaan, untuk memperoleh kehidupan yang lebih baik dari kehidupan di kampung. Dengan migrasi (merantau), tidak hanya kekayaan dan pengetahuan yang diperoleh, tetapi juga prestise dan kebanggaan pribadi (Hastuti, Thoyib, Troena, \& Setiawan, 2015).

Meskipun secara tradisional rantau merupakan wilayah ekspansi, daerah perluasan atau daerah taklukan sebagaimana di paparkan di atas. Namun dalam perkembangannya, konsep rantau dilihat sebagai sesuatu yang menjanjikan harapan untuk masa depan dan kehidupan yang lebih 
baik dikaitkan dengan konteks sosial ekonomi dan bukan dalam konteks politik. Berdasarkan konsep tersebut, merantau adalah untuk pengembangan diri dan mencapai kehidupan sosial ekonomi yang lebih baik. Dengan demikian, tujuan merantau sering dikaitkan dengan tiga hal: mencari harta (berdagang/menjadi saudagar), mencari ilmu (belajar), atau mencari pangkat dalam hal ini adalah pekerjaan atau jabatan (Navis, 1984). Kekhasan kultur minang dalam berwirausaha menunjukkan identitas Minang itu sendiri. ada pengaruh budaya tertentu (budaya menentukan) dengan perilaku kewirausahaan (Morrison, 2006).

Kebanyakan orang-orang Minangkabau pergi merantau ketika berusia belasan tahun. Kondisi ini secara langsung atau tidak langsung akan berpengaruh terhadap keberlangsungan sistem kekerabatan matrilineal Minangkabau dengan segenap nilai-nilai yang melingkupinya. Namun ada yang unik dari para perantau Minang ini, walaupun mereka hidup di perantauan mereka tetap bisa menunjukkan identitas kulturalnya. Orang-orang Minangkabau di perantauan tetap tampil sebagai urang awak (Muarif, 2009). Orang Minangkabau dikatakan cinta budaya, pernyataan ini seolah tak terbantahkan. Di mana mereka merantau, selalu menunjukkan identitas budayanya. Dimulai dari orientasi musiknya, masakan padang nya. Kemanapun mereka berada, mereka selalu menjadi urang awak. Ikatan kekeluargaan yang kuat di kalangan masyarakat Minangkabau dapat dilihat pada pantun ini: "Berek-berek turun ke semak, dari semak turun ke padi, dari nenek turun ke mamak, dari mamak turun ke kami”. Pantun tersebut menjadi penanda kuatnya ikatan antara orang Minangkabau dengan leluhurnya (Muarif, 2009, hal. 102). Seiring dengan tradisi di atas, banyak orang Minangkabau yang akhirnya menetap di perantauan, membina hidup bersama yang berpotensi mempererat hubungan antara suami terhadap istri dan anak-anaknya. Dengan semakin eratnya hubungan suami dengan keluarga intinya, maka-pudarnya relasi laki-laki Minangkabau dengan kerabat matrilinealnya bakal menjadi keniscayaan. Bukan tidak mungkin orang Minangkabau akan tercabut dari akar adatnya, dan melupakan kerabatnya, untuk selanjutnya para laki-laki pemuda Minang tersebut "meninggalkan" kewajibankewajibannya yang telah ditentukan oleh adat, antara lain: penjaga harta kaum dan sebagai penerus fungsi mamak.

Suatu masalah yang belum banyak dikaji tentang para perantau Minangkabau masa kini adalah mengenai perubahan sistem nilai serta kehidupan sosial mereka. Lamanya waktu dan jauhnya tempat merantau bukan tidak mungkin memudarkan kedekatan, ketaatan dan kesetiaan laki-laki Minangkabau pada adat leluhurnya, kecuali apabila para perantau Minangkabau tersebut tetap intensif dalam membina hubungan dengan kerabat di kampung halamannya. Untuk itulah kajian ini bertujuan, pertama untuk menggambarkan hal-hal yang melatarbelakangi laki-laki Minangkabau pergi merantau meninggalkan kerabatnya, dan kedua menggambarkan usaha para laki-laki Minangkabau perantauan dalam membina hubungan dengan kerabat asal dan dengan sesama perantau

\section{Metode}

Penelitian yang merupakan penelitian deskriptif kualitatif ini bertujuan untuk menggambarkan latar belakang laki-laki Minangkabau merantau ke kota Yogyakarta dan usaha para perantau tersebut dalam menjaga hubungan kekerabatan dengan kerabat di kampung halamannya. Penelitian dilakukan di lingkungan Keluarga Besar Minangkabau Yogyakarta yang merupakan sebuah organisasi yang menghimpun dan beranggotakan orang-orang Minangkabau yang merantau dan menetap di Daerah Istimewa Yogyakarta.

Subjek penelitian ditentukan secara snowball. Langkah pertama dengan menentukan key informan, yaitu seorang pengurus Keluarga Besar Masyarakat Minangkabau Yogyakarta, yang mengetahui 
secara

pasti tentang adat istiadat Minangkabau, serta mempunyai pengetahuan yang memadai tentang anggota himpunannya, yang selanjutnya akan menginformasikan siapa laki-laki Minang sebagai mamak yang sudah cukup lama merantau di Yogyakarta

Data penelitian ini dikumpulkan melalui wawancara dan studi dokumen, dan untuk kesahihan data pada tahap kegiatan pengumpulan data, dilakukan dengan cara penciptaan rapport yang baik dengan para informan; melakukan peer-debriefing dengan teman sejawat, dan melakukan crosscheck sumber data dan metode pengumpulan data. Analisis data yang dilakukan dalam penelitian ini adalah analisis induktif yang dilakukan sejak awal pengumpulan data sampai akhir pengumpulan data yang bersifat terbuka. Diawali dari reduksi data yang menghasilkan data yang relevan dan bermakna, dilanjutkan dengan menyusunnya ke dalam unit-unit dan kategori yang sesuai. Selanjutnya dilakukan display atau penyajian data dalam bentuk narasi.

\section{Hasil dan Pembahasan}

Fenomena perantauan Minangkabau ini telah berlangsung sejak tahun 1830 dengan kuantitas tiap tahunnya terus membesar, bahkan pada tahun 1971 telah mencapai $50 \%$ (Naim, 1984, hal. 30-33). Secara teoretis, ketika orang Minang merantau maka akan terjadi akulturasi budaya yang memungkinkan terjadinya penguatan atau malah perubahan budaya, yang muncul dalam bentuk meninggalkan adat aslinya. Karena dengan bertambahnya pengetahuan dan semakin luasnya wawasan masyarakat Minangkabau akan melahirkan sikap kritis terhadap sistem kekerabatan matrilineal, khususnya dalam hubungan antara ayah dengan anak dan kemenakannya. Dimana dalam sistem ini, seorang suami diperlakukan sebagai "orang asing" di lingkungan kerabat istri dan tidak memiliki otoritas terhadap anak-anaknya. Sementara di lingkungan kerabat ibunya, saudara perempuanlah yang dominan. Posisi tersebut secara sosial menjadi faktor pendorong timbulnya tradisi merantau orang Minang (Naim, 1984).

Sebagai suatu fase kehidupan yang harus dilalui adalah oleh laki-laki Minangkabau, merantau merupakan proses interaksi dengan dunia luar yang akan memperkaya wawasan mereka. Meninggalkan kampung halamannya menuju daerah baru yang mempunyai tradisi berbeda, merupakan titik krusial keberadaan sistem nilai yang hidup dan berkembang dalam masyarakat Minangkabau. Dengan berpedoman pada falsafah hidup dimana bumi dipijak, disitu langit dijunjung maka orangorang Minangkabau yang berada di daerah baru akan senantiasa belajar dan beradaptasi sehingga dapat diterima sebagai bagian dari masyarakat di daerah baru yang mereka tempati. Alam terkembang menjadi guru merupakan sikap hidup orang Minangkabau yang akan senantiasa belajar seiring dengan berubahnya fenomena yang dijumpai di perantauan. Namun relasi dengan dunia luar tersebut bukan hanya memperkaya kebudayaan mereka, tetapi juga dapat mengakibatkan terkikisnya nilai-nilai lama yang dianut oleh masyarakat Minangkabau.

Banyak alasan yang melatarbelakangi para laki-laki Minangkabau merantau ke Yogyakarta. Responden dalam penelitian ini yang merupakan sebagian kecil dari keluarga Minangkabau yang merantau dan hidup di Yogyakarta dengan tujuan untuk mencari sumber penghidupan, dan mencari pengalaman. Di Minangkabau, mereka berenam merupakan mamak rumah atau mamak kepala waris, yang juga lazim disebut dengan istilah tungganai. Apabila mengacu pada adat Minangkabau, mereka mempunyai kewajiban-kewajiban tertentu terhadap kemenakan atau anak dari saudara-saudara perempuannya, juga terhadap keluarga ibunya.

Laki-laki Minangkabau harus bisa mandiri secara ekonomi. Oleh karena itu kebanyakan perantau akan merantau keluar dari kampung halamannya. Mereka banyak yang menjadi pedagang, pengusaha rumah makan padang, pengusaha kain ataupun 
membuka usaha yang lain tujuannya adalah untuk mencari kehidupan yang lebih baik. Ciri dari suku Minang lainnya yang menonjol adalah budaya menggaleh atau berdagang. Walaupun tidak sedikit orang Minangkabau yang bekerja di pemerintahan, mempunyai profesi lainnya yang cukup banyak jumlahnya dan berhasil, tetap saja yang menonjol atau dikenal umum itu adalah profesi dagangnya. Demikian bahwa menerima gaji dan menjadi buruh bukanlah budaya yang dibanggakan oleh masyarakat Minang yang sedang merantau (Bungo \& Hussin, 2011).

Jika ditelusuri, merantau merupakan penyiapan laki-laki Minangkabau terhadap kondisi alam sebagian Sumatra Barat yang merupakan daerah bergunung-gunung, dan berbukit-bukit dengan lembahnya yang curam sehingga tidak cukup representatif untuk mengembangkan areal pertanian. Di atas tanah yang serba terbatas tersebut, tidak mampu mengimbangi jumlah penduduknya yang terus bertambah, sehingga tekanan untuk menjual atau menggadaikan tanah pusaka menjadi makin kuat. Dengan dijual atau digadaikannya tanah pusaka, maka telah terjadi perubahan dalam hal kepemilikan tanah, yaitu dari kepemilikan yang bersifat komunal oleh kerabat menjadi kepemilikan yang bersifat individual. Perubahan hak kepemilikan tanah pusaka ini, niscaya akan merusak bangunan sistem kekerabatan matrilineal. Hal ini selaras dengan pendapat Naim (Naim, 1984, hal. 84) bahwa revolusi pertanian jelas telah menciptakan sikap perilaku ekonomi masyarkat. Perubahan sikap terhadap tanah dan terhadap sistem kepemilikan tanah juga timbul karenanya. Secara tradisional, tanah dimiliki oleh keluarga garis ibu dan menggadaikan atau penjualan tanah hanya dapat dilakukan dengan syarat-syarat tertentu. Akan tetapi dengan munculnya ekonomi uang dan kebutuhan akan uang tunai, masyarakat harus menggadai atau menjual tanah pusaka. Konsekuensi lebih lanjut dari ekonomi uang adalah perkembangan individualisme yang pesat dengan proses individualisasi dari pemilikan harta kekayaan dan di atas segalanya itu, rusak bangunan kekeluargaan matrilineal yang selama ini terjalin erat.

Kondisi ekonomi di kampung yang semakin sulit membulatkan tekad laki-laki muda Minangkabau merantau ke kota-kota besar di luar kampungnya. Kota yang "menjanjikan" untuk memberikan kesejahteraan yang lebih baik telah menggerakkan anak-anak muda di kampung untuk hidup di daerah perkotaan. Inilah titik awal perubahan budaya di Minangkabau, karena ternyata merantau menjadi momentum awal laki-laki Minangkabau terlepas dari keluarga matrilinealnya. Naim (1984) menggambarkan bahwa sarana lebih modern, dan daya tarik kota-kota di Indonesia, dan di dorong oleh faktor dari dalam, mengakibatkan semakin banyak laki- laki Minangkabau merantau. Gejala tersebut mengakibatkan laki-laki membawa istri dan anak-anak mereka ke rantau dan mendorong pembentukan keluarga inti yang hidup lepas dari keluarga matrilinealnya. Pada saat itu mulailah berkembang pola menetap setelah menikah yang bersifat neo lokal terutama di daerah perkotaan yang terdiri dari ayah, ibu dan anak-anak. Tujuan dari budaya merantau dari budaya merantau selain mencari ilmu, serta menaikkan martabat keluarga. Selain itu, bagi kaum laki-laki yang tidak mempunyai hak menggunakan tanah waris untuk keperluan, merantau salah satu cara untuk menambah kekayaan tanpa menggunakan tanah yang telah ada (Yulanda, 2016).

Paparan di atas diperkuat dengan kenyataan di lapangan bahwa kesuksesan laki-laki Minang di perantauan akan menaikkan atau menurunkan harga diri lakilaki itu di kampungnya. Para laki-laki yang merantau tersebut biasanya tidak pulang sebelum berhasil secara ekonomi. Tak seorang pun di kampung halaman yang mengetahui apa yang dialami di perantauan, karena pantang bagi para laki-laki itu mengabarkan kegagalannya. Keberhasilan laki-laki Minang di perantauan akan menaikkan pamor mereka di kampung 
halaman. Kesuksesan para perantau seringkali diukur dari sering tidaknya berkirim uang ke kampungnya, baik untuk kepentingan kerabat ibunya ataupun untuk mempermegah rumah kerabat. Semakin sering berkirim uang, niscaya di kampung mereka menjadi buah bibir yang berdampak pada makin banyaknya yang berkehendak mengambilnya menjadi menantu. Lazimnya para perantau ini beristrikan pilihan orang tuanya dengan persetujuan dari ninik-mamaknya. Perjodohan itu dilakukan saat mereka masih di rantau, bahkan terkadang laki-laki yang merantau tersebut juga tidak mengenal perempuan tersebut. Umumnya mereka menyetujui rencana perjodohannya dengan perempuan pilihan keluarganya karena mereka berpegang pada pepatah apo nan tabaik kecek urangtuo, itulah nan tabaik untuk kito. Pendidikan merupakan salah satu hal yang sangat penting bagi laki-laki Minangkabau. Ini selaras dengan penuturan dua responden asal Bukittinggi dan Solok, yang berprofesi sebagai seorang pengajar dan profesional. Mereka tinggalkan kampung halaman untuk mendapatkan pendidikan di kota Yogyakarta. Alasannya karena kota di Jawa dianggap memiliki fasilitas dan kualitas yang sangat menunjang. Seperti penuturannya proses perantauannya diawali dengan kedatangannya ke kota ini untuk melanjutkan studi. Pemaknaan mahasiswa perantau tentang budaya merantau Minangkabau adalah suatu kebiasaan yang dilakukan oleh orang Minangkabau secara turun temurun untuk keluar/pergi dari daerah asal ke daerah baru, baik oleh laki-laki maupun perempuan, sebagai bentuk pembuktian kemandirian diri dengan tujuan bekerja, berdagang, menuntut ilmu, dan memperbaiki tali silaturrahmi dengan harapan mendapat kehidupan yang lebih baik, baik di daerah rantau maupun di daerah asal (Marta, 2014).

Dari penuturan para responden bahwa merantau menjadi sarana mencari pengalaman, dan menambah pengetahuan agar tidak seperti "katak dalam tempurung". Diyakini bahwa merantau merupakan salah satu proses pendewasaan diri bagi laki-laki untuk menjemput tugas berat yang kelak akan dipikulnya. Di Minangkabau terdapat dua rumah yang sangat bermakna bagi seorang laki-laki, yang pertama adalah rumah ibu, dan yang kedua adalah rumah istri. Di rumah ibu, seorang laki-laki akan berperan menjadi mamak dan di rumah istri berperan sebagai urang sumando. Di kedua rumah tersebut setiap laki-laki Minang mempunyai tugastugas yang harus ditunaikan sesuai perannya. Laki-laki Minangkabau yang melakukan perantauan untuk menuntut ilmu biasanya meninggalkan kampung halamannya pada usia belasan tahun tanpa keterampilan dan pengalaman yang cukup memadai.

Tradisi merantau pada masyarakat Minangkabau merupakan suatu cara yang dilakukan untuk menunjukkan suatu kesuksesan dan kematangan dari para pemuda, terutama kaum laki-laki Minangkabau. Bagi kaum laki-laki Minangkabau melakukan perantauan tidak hanya ilmu pengetahuan dan harta kekayaan yang didapat, melainkan juga suatu kehormatan dan prestise secara individu ditengah-tengah lingkungan masyarakat adat orang Minangkabau selalu mendorong kaum mudanya untuk melakukan perantauan, dan apabila mereka kembali harus membawa keberhasilan karena telah mendapatkan ilmu pengetahuan yang banyak atau harta berlimpah karena usaha yang dilakukan di daerah perantauan maju. Selain meningkatkan kehidupan ekonominya, pedagang Minang juga berjaya meningkatkan taraf pendidikan dan sosial keluarga mereka di tanah rantau yang bermakna bahwa merantau dan berdagang adalah salah usaha mempertingkatkan status keluarga (Bungo \& Hussin, 2011). Mereka tidak akan kembali ke daerah asal apabila belum mendapatkan kesuksesan. Mereka akan bertahan hidup di perantauan, larut di daerah perantauan atau bahkan tidak akan kembali kedaerahan asal sebelum mendapatkan kesuksesan (laruit dirantau urang).

Jurnal Civics: Media Kajian Kewarganegaraan |31 
Budaya merantau merupakan bagian dari budaya laki-laki Minangkabau. Nenek moyang dari suku Minangkabau telah melakukan perantauan sejak berabad silam, untuk mendapatkan ilmu dan penghidupan yang lebih baik. Anak-anak Minangkabau merupakan bibit yang telah disemaikan di lingkungan alam Minangkabau, yang agar dapat tumbuh baik dan berkualitas, harus dipindahkan ke lahan yang lebih luas. Lahan yang luas itu adalah wahana perantauan. Dengan kata lain apabila tetap tinggal di kampung halaman, tidak akan bertambah wawasan dan ilmunya. Ini selaras dengan pepatah yang mengatakan "kalau hidup di celah ketiak orang sampai tua tak akan menjadi orang". Atau dalam pepatah lain dikatakan "kalau melekap di celah ketiak, sampai mati tak dapat tegak" (Muarif, 2009, hal. 59). Adat Minangkabau merupakan aturan yang mengatur kehidupan orang Minangkabau. Aturan tersebut bersifat mengikat bagi orang Minangkabau tidak melaksanakan adat Minangkabau, tidak beradat dengan adat Minangkabau maka orang tersebut dianggap telah melanggar adat Minangkabau (Munir, 2013).

Mengacu adat yang berlaku sebagai seorang mamak dengan sebutan "tungganai", laki-laki Minang berkewajiban menjaga dan melindungi harta pusaka, dengan cara mengawasi penggunaan harta pusaka yang dikuasai dan dikelola oleh perempuan tertua dalam rumah gadang. Ibulah yang mengatur penggunaan harta pusaka untuk kehidupan dan kesejahteraan semua anggota keluarganya, sehingga seluruh anggota dapat memanfaatkan harta pusaka untuk kepentingan hidupnya sehari-hari dengan memakai hak ganggam beruntuk. Ini mengandung arti pemilikan yang semi karena boleh memiliki hasil dari harta pusaka yang digarapnya, akan tetapi tidak memiliki tanahnya. Di sinilah peran pokok laki-laki Minangkabau dalam menjaga kelangsungan harta pusaka. Seorang laki-laki hanya boleh menambah dan tidak boleh mengurangi sehingga harus dijaga agar harta pusaka tidak menjadi berkurang karena dijual ataupun digadaikan. Sedangkan di rumah istrinya di samping berkewajiban untuk mengembangkan keturunan, laki-laki berkewajiban untuk menafkahi anak dan istrinya.

Untuk melaksanakan tugas-tugas berat ini, kemandirian laki-laki Minang telah dipersiapkan sejak dini. Terbukti sejak masih kecil laki-laki Minang sudah harus ditempa fisik dan mentalnya. Sehingga hanya di waktu masih kecil saja laki-laki Minang tidur di rumah ibunya, karena setelah lebih besar anak laki-laki lebih banyak mengaji di surau. Di rumah nyaris tidak ada bilik yang disediakan untuk anak laki-laki karena bilik untuk anakanak perempuan. Tidur di surau akan membentuk anak laki-laki Minang menjadi pemuda yang kuat beribadat, luwes bermasyarakat, dan terampil dalam mengurus diri sendiri. Anak-anak muda yang telah cukup akal dan telah pula matang dengan pengajaran, akan dimotivasi untuk merantau, meninggalkan kampung halamannya. Bagi laki-laki Minang, merantau merupakan rite de passage atau gerbang inisiasi yang harus dilalui dan proses pendewasaan diri, untuk mempersiapkan kehidupan yang lebih baik.

Semangat kerukunan yang bermuara dari bakat daya baur antar suku juga diajarkan oleh adat dan budaya Minangkabau "di mano bumi dipijak di sinan langit dijunjuang" (dimana bumi dipijak di sana langit dijunjung) dikaitkan dengan "kalau buyuang pai marantau induak cari dunsanak cari, induak samang cari dahulu" (kalau buyung pergi merantau cari orang tua (dituakan), cari saudara, terlebih dahulu mencari induk semang) artinya adalah sandaran atau landasan berpijak di daerah baru yang perlu dicari dan dikokohkan lebih dahulu. Ini adalah ajaran turun-temurun yang mendarah daging yang terbukti dan teruji mempunyai nilai yang sangat tinggi yang makin dirasakan saat ini.

Bagi laki-laki Minang merantau erat kaitannya dengan pesan nenek moyang "keratau madang di hulu babuah babungo balun" (anjuran merantau kepada 
laki-laki karena di kampung belum berguna). Dalam kaitan para perantau juga harus memahami pesan yang terkandung dalam ungkapan "satinggi-tinggi tabangnyo bangau kembalinya ke kubangan juo”. Ungkapan ini ditujukan agar orang Minangkabau akan selalu ingat pada ranah asalnya, karena banyak perantau asal Minangkabau yang menetap bahkan, sampai meninggal dunia dan dimakamkan di daerah perantauannya. Pada umumnya para perantau Minangkabau ini mampu menyesuaikan dengan adat istiadat serta kebudayaan daerah yang menjadi tujuan rantaunya. Masyarakat Minangkabau yang merantau tidak pernah terlibat konflik dengan masyarakat yang menjadi tempat perantauannya. Mereka menyelaraskan diri dengan ajaran adat Minangkabau yang berbunyi "dimano bumi dipijak, disitu langit dijunjung ", sehingga orang-orang Minangkabau yang berada di daerah baru akan senantiasa belajar dan beradaptasi dengan lingkungannya, sehingga dapat diterima menjadi bagian dari masyarakat di daerah baru yang mereka tempati

Alasan untuk merantau setiap orang Minangkabau bisa berbeda-beda. Namun yang menjadi menarik adalah keberanian mereka untuk memutuskan untuk merantau meninggalkan kampung halaman. Suatu tindakan yang mungkin tidak semua laki-laki muda berani melakukannya. Uniknya lagi mereka yang merantau ini masih sangat muda usia berusia belasan tahun. Selain itu mereka relatif belum mempunyai keterampilan apaapa dan belum memiliki pengalaman keluar dari kampungnya. Mereka hanya bermodal tekad dan semangat yang kuat. Munculnya semangat yang begitu kuat tanpa dilandasi oleh keterampilan yang mencukupi semakin memperkuat anggapan bahwa merantau merupakan fase kehidupan laki-laki Minangkabau. Maka setiap laki-laki Minangkabau harus melewatinya. Dengan merantau, para laki-laki Minangkabau telah membuktikan dirinya telah dewasa dan mampu bertanggung jawab.
Seiring dengan tradisi merantau tersebut di atas, banyak orang Minangkabau yang akhirnya menetap di perantauan dan membina rumah tangga serta menempati rumah yang mereka miliki sendiri sehingga peranan lakilaki sebagai ayah dalam keluarga semakin menonjol dan mempererat hubungan antara suami terhadap istri dan anak-anaknya. Dengan semakin eratnya dekatnya hubungan suami dengan istri dan anak-anaknya, maka renggangnya hubungan laki-laki Minang dengan kerabat asalnya akhirnya menjadi keniscayaan. Bukan tidak mungkin orang Minangkabau akan tercabut dari akar adatnya dan melupakan kerabatnya serta "meninggalkan" kewajiban-kewajibannya sebagai mamak, yakni menjaga, membina dan membimbing kemenakan.

Sebagai urang awak yang berada di perantauan tetap membina hubungan dengan kerabat asal dalam arti merantau bukan sesuatu hal yang akan memutuskan kekerabatan. Terbentuknya keluarga di Yogyakarta yang terdiri dari ayah, ibu dan anak yang secara fisik berada cukup jauh dari kerabat asalnya membuat mereka mengalami pola hidup yang berbeda. Selain itu di Yogyakarta mereka bergaul dengan anggota masyarakat yang berbeda suku, berbeda latar belakang pendidikan dan sosial, dan berbeda juga sistem kekerabatannya, yang lambat laun memang memengaruhi para perantau asal Minang ini. Dengan kata lain pergi merantau sedikit banyak memengaruhi pola pikir, pola pergaulan, pola asuh dan sebagainya.

Dengan merantau dan meninggalkan teritorial Minangkabau, maka pengaruh dan kekuasaan adat Minang menjadi melemah terhadap keluarga Minangkabau di rantau. Dengan meninggalkan teritorial Minangkabau, berarti pula keluarga meninggalkan harta pusaka dan mulai terlepas dari akar hukum adatnya. Merantau ke Yogyakarta dengan membawa serta anak istri menyebabkan adanya perubahan, antara ain dalam hal relasi antara suami istri, menguatnya otoritas ayah kepada anak- 
anaknya dan berkurangnya intensitas peran mamak kepada kemenakan.

Namun demikian, para perantau tetap memiliki hubungan dengan keluarga asalnya, terutama perantau yang sudah berkeluarga atau berumah tangga. Mereka menyadari akan tugas dan kewajibannya terhadap keluarga luas matrilinealnya, yakni memelihara, dan membimbing kemenakan seperti anak kandung sendiri, serta mengawasi pemanfaatan harta pusaka. Tugas sebagai mamak tetap dilakukan para perantau tersebut, meskipun ada beberapa yang mungkin akan diwakilkan. Apabila ada kemenakan yang mempunyai masalah yang berhubungan dengan hidup bermasyarakat di tingkat korong atau kampung, meskipun berada di perantauan, para laki-laki yang berkedudukan sebagai mamak tetap berusaha terlibat menyelesaikannya. Keterlibatannya bisa dilakukan secara langsung, pulang ke kampung dan berpartisipasi dalam musyawarah. Bisa juga dengan pemberian nasihat serta solusi yang disemaikan melalui surat ataupun bertelepon. Apabila permasalahan kemenakan berada di tingkat nagari, para perantau menyerahkan penyelesaian masalah tersebut sepenuhnya kepada ninik mamak dan penghulu atau datuk-datuk kaum, bersama alim ulama cerdik pandai serta pemerintahan nagari di Balai Adat yang disebut Balerong dalam kerapatan adat nagari.

Karena mamak jarang bertemu langsung dengan kemenakan, maka pendidikan dan bimbingan dilakukan oleh mama melalui sarana komunikasi yang ada, misalnya surat atau telepon. Apabila berkomunikasi melalui sarana itu pun masih terkendala, interaksi dan berkomunikasi dengan kemenakan akan dilakukan apabila dirasa perlu saja. Itulah sebabnya, jika laki-laki Minang yang berposisi sebagai mamak pergi merantau, dirinya akan mencari pengganti, saudara lakilaki atau saudara sepupunya yang dipercaya, yang tetap tinggal di kampung. Selanjutnya mamak tersebut mewakilkan tugas dan perannya kepada tungkik atau wakilnya tersebut.

Laki-laki Minangkabau yang merantau akan melakukan tugasnya dengan baik sebagai mamak, apabila mampu secara ekonomi. Fenomena ini terlihat pada para responden ini, sebagaimana penuturan mereka, yang terus berupaya untuk dapat menyokong kebutuhan ekonomi kerabat asalnya di kampung. Para laki-laki Minangkabau yang ada di perantauan tetap menggunakan bahasa Minang dalam berkomunikasi dengan para anggota keluarganya. Semua responden bersepakat menggunakan bahasa Minang untuk berkomunikasi dengan keluarga, khususnya dengan anak-anak dengan tujuan menumbuhkan kesadaran dalam diri anakanak bahwa mereka keturunan Minangkabau, walaupun mungkin mereka tidak pernah menginjakkan kakinya di tanah Minang. Untuk memperkuat eksistensi "keminangan" mereka, mereka secara aktif terlibat dalam organisasi kedaerahan, misalnya menjadi anggota Keluarga Besar Minangkabau Yogyakarta. Di organisasi ini, mereka bertemu sebulan sekali. Dalam pertemuan tersebut, banyak hal tentang "keminangan" mereka bicarakan. Dengan cara ini mereka saling berbagi kerinduan kepada kampung halaman pada satu sisi dan membangun solidaritas sosial dan kultural di antara mereka. Cara ini dilakukan oleh masyarakat Minangkabau untuk terus menjaga identitasnya sebagai orang Minangkabau di tengah kehidupan orang-orang Yogyakarta.

Uraian di atas mengindikasikan tetap adanya hubungan antara perantau dengan kampung halaman yang bersifat riil. Hubungan dengan kampung halaman ini dapat dibedakan menjadi dua hal, yang pertama adalah keterikatan kepada tradisi yang dapat dilihat pada masih digunakannya kebiasaan-kebiasaan yang biasa dilakukan di kampung halaman. Kedua adalah keterikatan secara fisik pada kampung halaman, yang dapat ditelusuri dari pengiriman uang ke kampung halaman, baik untuk kepentingan 
keluarga luas matrilinealnya sendiri seperti membiayai ibu dan kemenakan, ataupun untuk kepentingan masyarakat seperti pembangunan masjid, perbaikan jalan dan jembatan dan sebagainya.

Selama di perantauan para laki-laki Minang mudah sekali bersosialisasi dengan warga sekitar dimana mereka tinggal. Meskipun identitas kultur mereka tidak hilang, seperti bahasa mereka masih banyak yang menggunakan bahasa asli. Seperti dalam pepatah melayu yang diungkapkan "sekali air bah, sekali pantai berubah". Pepatah ini menggambarkan bahwa orang-orang Minangkabau siap menerima perubahan ketika sedang berada di perantauan. Kemampuan mereka dalam beradaptasi telah diwarisi secara turun temurun lewat peninggalan para leluhur. Orang Minangkabau selalu terbuka kepada siapa saja, tanpa melihat latar belakang orangnya (Muarif, 2009, hal. 78). Oleh karena itu, orang Minangkabau bisa terbuka kepada siapa saja tanpa melihat latar belakang orang itu berasal. Hal tersebut yang membuat mereka di perantauan ada yang menjadi pengusaha, dosen, maupun tokoh penting di kota perantauan.

Fenomena menarik lain dari tradisi merantaunya orang Minangkabau adalah penciptaan relasi atau interaksi sosial sebagai usaha untuk beradaptasi dengan lingkungan dan budaya yang ditemukan di rantau. Penciptaan hubungan (jejaring) dengan sesama perantau Minang ini dimulai sejak seseorang menginjakkan kakinya di perantauan. Caranya adalah dengan mencari dan menemukan orang Minangkabau yang lebih dahulu merantau di daerah itu. Kepada mereka inilah orang-orang yang merantau itu pertama kali meminta bantuan dan menjadi tempat berteduh (Naim, 1984, hal. 179). Hal tersebut selaras dengan pesan mamak yang disampaikan sebelum mereka tinggalkan kampung halaman yakni "jika waang pai bajalan, dima bumi dipijak di sinan langik dijunjuang, di sinan rantiang dipatah, disinan aie disauak, ibu cari bapa cari, induak samang cari dahulu, urang kampuang dipatenggangkan". Pesan ini benar-benar dihayati dan dilaksanakan oleh orang-orang Minang yang tinggal dan berdiam di Yogyakarta, dengan menciptakan jejaring sosial baru, dengan cara mencari saudara, orang tua serta teman terlebih dahulu untuk "bersandar", serta untuk belajar mengenai kebiasaan-kebiasaan setempat. Nasib sebagai sesama perantau merupakan pengikat mereka untuk saling membantu. Tidak mengherankan jika di Yogyakarta banyak berdiri perhimpunan perantau asal Minang, seperti Baringin Mudo, Wanita Baringin, dan Keluarga Minangkabau Yogyakarta. Selain itu beberapa organisasi lokal Sumatra Barat juga mendirikan asrama, seperti Daerah Maninjau mendirikan asrama" Tanjung Raya", nagari Sulik Aie mempunyai asrama" Gunung Merah" dan nagari Banuhampu mempunyai asrama" Banuhampu". Sakali aia gadang, sakali tapian baraliah merupakan pepatah adat yang merefleksikan kesadaran masyarakat Minangkabau bahwa masyarakat dan kebudayaannya akan senantiasa berubah. Itulah sebabnya peristiwa merantau yang dapat berdampak pada perubahan-perubahan tidak menimbulkan reaksi yang berlebihan.

\section{Simpulan}

merantau merupakan fase kehidupan yang selayaknya dilalui oleh masyarakat Minangkabau sebagai sarana membuktikan pendewasaan diri dan tanggung jawabnya. Dominasi perempuan sebagai penguasa harta pusaka di lingkungan kerabat ibunya, memang menyisakan lemahnya posisi lakilaki. Dengan merantau, mereka bisa terlepas dari ikatan sistem kekerabatan matrilineal dan membangun "kewibawaan" sebagai seorang suami dan ayah. Tradisi merantau tersebut berdampak pada banyaknya orang Minangkabau yang akhirnya menetap di perantauan, membina rumah tangga serta menempati rumah yang mereka miliki sendiri sehingga peranan laki- laki sebagai ayah dalam keluarga semakin menonjol dan mempererat hubungan antara suami terhadap 
istri dan anak-anaknya. Namun tidak berarti hubungan riil maupun hubungan imajiner dengan kampung halaman menjadi terputus. Berbagai usaha dilakukan para perantau untuk menjalin hubungan dengan kerabat luas matrilinealnya. Dalam membina hubungan dengan kerabat asal dan kampung halaman, para perantau yang berstatus sebagai mamak tetap menjalankan sebagian fungsinya dengan menjalin komunikasi serta terlibat aktif apabila ada permasalahan yang menimpa kemenakan. Pemberian nasihat juga diberikan oleh para perantau, kala mereka yang di kampung halaman bermaksud menggadaikan atau mengalihkan harta pusaka. Selain itu mobilisasi dana untuk kesejahteraan keluarga dan masyarakat di kampung halaman juga selalu dilakukan para perantau. Dalam membina hubungan dengan sesama perantau, dilakukan dengan menciptakan jaring-jaring sosial yang sangat bermanfaat bagi perantau yang baru datang untuk memahami dan menyesuaikan diri dengan budaya di daerah perantauan.

\section{Referensi}

Akmal, S. Z., \& Nurwianti, F. (2012). Kekuatan karakter dan kebahagiaan pada suku Minang. Jurnal Ilmiah Psikologi, $3(1)$.

Bungo, N., \& Hussin, N. (2011). Migration to Kuala Lumpur: the Minangkabau cultural tradition of out-migrating and trading. GEOGRAFIA Online, Malaysian Journal of Society and Space, 7(5), 116-131.

Hastuti, P. C., Thoyib, A., Troena, E. A., \& Setiawan, M. (2015). The Minang entrepreneur characteristic. Procedia Social and Behavioral Sciences, 211(September), 819-826. https://doi.org/10.1016/j.sbspro.2015.11 .108

Marta, S. (2014). Konstruksi makna budaya merantau di kalangan mahasiswa perantau. Jurnal Kajian Komunikasi, $2(1), 27-43$.

Morrison, A. (2006). A contextualisation of entrepreneurship. International Journal of Entrepreneurial Behavior \& Research, 12(4), 192-209.

Muarif. (2009). Rahasia sukses orang Minang di perantauan: Suku paling sukses merantau di Indonesia. Yogyakarta: Pinus Book Publisher.

Munir, M. (2013). Hidup di rantau dengan damai : nilai-nilai kehidupan orang Minangkabau dalam. Prosiding The 5th International Conference on Indonesian Studies: "Ethnicity and Globalization," 27-41.

Naim, M. (1984). Merantau: pola migrasi suku Minangkabau. Yogyakarta: Gajah Mada University Press.

Navis, A. A. (1984). Alam terkembang jadi guru: Adat dan kebudayaan Minangkabau. Jakarta: Grafiti Pers.

Wibisono, B. A. (2012). Modal sosial kelompok pedagang asal Minang di Kota Surakarta. Dialektika. Surakarta.

Yulanda, N. (2016). Pengaruh nilai budaya bisnis pada masyarakat minangkabau terhadap perilaku kewirausahaan pedagang perantau di Tanah Abang. JABE (Journal of Applied Business and Economic), 2(1), 95-108. 